\title{
PELAKSANAAN SURVEILANS KESEHATAN DAN KESIAPSIAGAAN MASYARAKAT PASCA ERUPSI MERAPI 2010 PADA PELAKSANAAN DESA SIAGA DI DESA TALUN KLATEN
}

\author{
Rio Rialdi ${ }^{1}$ dan Sunarto ${ }^{2}$ \\ ${ }^{1}$ Mahasiswa Fakultas Kedokteran Universitas Islam Indonesia \\ ${ }^{2}$ Kepala Departemen IKM Fakultas Kedokteran Universitas Islam Indonesia \\ Jl. Kaliurang Km 14,5 Yogyakarta
}

\begin{abstract}
Indonesia is one country that is classified as vulnerable to natural disasters. Merapi eruption is one of the natural disasters that have an impact on public health. Standby village is an important pillar in handling disasters, since people usually are not prepared if there is a sudden disaster. The purpose of the study was to determine the application program of public health surveillance and preparedness after the eruption of Merapi of 2010 in the implementation of standby village in Talun Village, Kemalang Sub-district, Klaten District Central Java. The research was descriptive using study case with qualitative analysis. The subject of the study was performers implementing public health surveillance program. The object of the study was the social situation in performing program. Informant was determined by purposive and snowball effect. Data were collected by non participative observation, interview, documentation, focus discussion group (FGD), and triangulation. Judging from some indicators, the implementation of standby village had been running well. The performing of public surveillance program has not been running properly due to lack of socialization of the health center. The community disaster preparedness program was good enough. However, it should be improved to preparedness upon health emergencies. Standby village program and community preparedness is good enough, however it is not followed by a good surveillance based on community.
\end{abstract}

Keywords: Surveillance, Public Preparedness, Standby Village

\section{PENDAHULUAN}

Indonesia merupakan salah satu Negara yang tergolong rawan terhadap bencana alam, hal tersebut berhubungan dengan letak geografis Indonesia yang terletak diantara dua samudera besar dan terletak di Wilayah lempeng tektonik (Depkes RI, 2005).

Gunung Merapi adalah gunung yang masih aktif hingga saat ini dan dianggap seagai gunung yang berbahaya di Indonsia. Sejak tahun 1548 gunung ini sudah meletus sebanyak 75 kali, letusan letusan kecil terjadi tiap dua sampai tiga tahunan yang lebih besar sekitar sepuluh sampai lima belas tahun sekali (Permanasari, 2010).

Letusan gunung berapi berdampak pada populasi masyarakat. Cedera traumatik, luka bakar yang cukup 
serius, gangguan pernafasan dan rusaknya fasilitas kesehatan, fasilitas umum serta rumah penduduk dapat terjadi. Dampak ini semakin rumit saat penduduk harus dievakuasi dan ditempatkan di pengungsian (PAHO, 2006). Masyarakat sering tidak siap ketika bencana terjadi. Untuk melindungi masyarakat dari kerugian yang besar dalam bencana maka perlu ada pengelolaan tanggap bencana, rekonstruksi atau rehabilitasi pasca bencana. Dalam hal ini, sebuah desa sangatlah berperan penting dalam mewujudkan hal tersebut, sehingga perlu adanya Desa Siaga (Permanasari, 2010).

Mengingat begitu pentingnya upaya pengurangan risiko bencana dalam pencapaian Millenium Development Goals (MDGs), maka United Nation - International Strategy for Disaster Reduction (UN-ISDR) mengadakan pertemuan internasional di Jenewa. Isu sentral yang melatarbelakangi pertemuan ini adalah kejadian-kejadian bencana yang semakin meningkat akhir-akhir ini yang telah menghancurkan berbagai infrastruktur kota-kota di dunia yang berdampak langsung pada macetnya pertumbuhan ekonomi dan rusaknya lingkungan. Sementara stabilitas pertumbuhan ekonomi dan daya dukung lingkungan adalah faktor penting yang sangat berpengaruh dalam pencapaian MDGs sebelum 2015 (Syahputra dkk, 2010).

Desa Siaga adalah desa yang penduduknya memiliki kesiapan sumber daya dan kemampuan serta kemauan untuk mencegah dan mengatasi masalah-masalah kesehatan secara mandiri dalam rangka mewujudkan Desa Sehat (Depkes RI, 2006). Desa Siaga dikembangkan sejak tahun 2006 sesuai dengan Keputusan Menteri Kesehatan Nomor 564 / Menkes / SK / VIII / 2006 tentang Pedoman Pelaksanaan Pengembangan Desa Siaga, telah berkembang dan masih terus perlu dilakukan pembinaan (Depkes RI, 2010).

Pada tahun 2015 ditargetkan 80\% kegiatan Desa Siaga telah aktif di seluruh kota atau kabupaten di Indonesia yang mengacu pada Standar Pelayanan Minimal (SPM), hal ini membuat propinsi Jawa Tengah berupaya lebih meningkatkan kesejahteraan masyarakatnya terutama dalam hal kesehatan, yaitu untuk membentuk Desa Siaga sesuai wewenang dan tanggung jawab masing-masing kota atau kabupaten (Depkes RI, 2010).

Di Jawa Tengah terdapat 35 kabupaten, salah satunya adalah kabupaten Klaten. Kabupaten Klaten mempunyai 20 kecamatan dan 208 desa. 80 desa diantaranya sudah menjadi desa siaga $(38,5 \%)$, salah satunya yaitu di kecamatan Kemalang. Kecamatan Kemalang memiliki 13 desa, 1 diantaranya merupakan Desa Siaga Tahap Purnama (Dinas kesehatan Klaten, 2010). Tingginya angka kematian di Indonesia, terutama kematian ibu yaitu sebesar 226/100.000 
kelahiran hidup, selanjutnya untuk angka kematian bayi sebesar 26/1000 kelahiran hidup (Dinas kesehatan Klaten, 2010). Tingginya angka kematian tersebut, menunjukkan masih rendahnya kualitas pelayanan kesehatan di Indonesia.

Beberapa kriteria indikator keberhasilan Desa Siaga adalah memiliki sistem pengamatan (surveilans) penyakit dan faktor-faktor resiko yang berbasis masyarakat serta memiliki sistem kesiapsiagaan dan penaggulangan kegawat daruratan bencana berbasis masyarakat (Depkes RI, 2006).

Desa Talun menjadi pilihan peneliti karena beberapa pertimbangan yaitu desa ini terletak di Kecamatan Kemalang dan termasuk kawasan Lereng Merapi. Desa Talun juga sudah ditetapkan oleh Dinas Kesehatan Propinsi Jawa Tengah sebagai Desa Siaga. Selain itu, desa ini juga diduga memiliki sumber data dan informasi mengenai permasalahan surveilans kesehatan dan Kesiapsiagaan masyarakat yang dapat dimasukkan kedalam penelitian ini.

\section{METODE PENELITIAN}

Penelitian ini adalah penelitian deskriptif menggunakan rancangan penelitian studi kasus (case study). Penelitian ini dilakukan dengan menggunakan menggunakan analisis kualitatif.

Metode penelitian kualitatif adalah metode yang digunakan untuk meneliti pada kondisi objek yang alamiah dimana peneliti sebagai instrumen kunci, teknik pengumpulan data dilakukan secara triangulasi (gabungan), analisis data bersifat induktif berdasarkan fakta-fakta yang ditemukan dan kemudian dapat dikonstruksikan menjadi hipotesis atau teori dan hasil penelitian kualitatif lebih menekankan makna daripada generalisasi. Metode penelitian ini muncul karena terjadi perubahan paradigma dalam memandang suatu realitas/fenomena/gejala. Dalam paradigma ini realitas sosial dipandang sebagai sesuatu yang holistik, kompleks, dinamis dan penuh makna (Sugiyono, 2008).

Obyek dan informan (subyek) penelitian kualitatif adalah menjelaskan obyek penelitian yang fokus dan fokus penelitian yaitu apa yang menjadi sasaran. Informan penelitian merupakan subyek yang memahami informasi obyek penelitian sebagai pelaku maupun orang lain yang memahami obyek penelitian (Bungin, 2007).

Penelitian kualitatif itu tidak menggunakan istilah populasi tetapi dinamakan "social situation" atau situasi sosial yang terdiri dari tiga elemen yaitu : tempat (place), pelaku (actors) dan aktivitas (activity) yang berinteraksi secara sinergis. Penelitian berangkat dari kasus tertentu yang ada pada situasi sosial tertentu dan hasil kajiannya tidak akan diberlakukan ke populasi 
tetapi ditransferkan ke tempat lain pada situai sosial yang memiliki kesamaan dengan situasi sosial pada kasus yang dipelajari. Demikian pula sampel dalam penelitian kualitatif bukan dinamakan responden tetapi sebagai narasumber atau partisipan, informan, teman dan guru dalam penelitian (Sugiyono, 2008).

1. Tempat (Place)

Desa Talun, Kecamatan Kemalang, Kabupaten Klaten

2. Pelaku (Actors)

Masyarakat setempat, tokoh masyarakat, kader kesehatan terkait desa siaga, tenaga kesehatan dan bidan.

3. Aktivitas (Activity)

Pelaksanaan program Surveilans Kesehatan dan Kesiapsiagaan Masyarakat.

Obyek penelitian yang ingin diteliti adalah situasi sosial dalam pelaksanaan program UKBM dan KADARZI, sehingga peneliti dapat mengamati secara mendalam aktivitas (activity), dan orang-orang (actors) yang ada pada Desa Talun (place). Teknik Pengumpulan data yang digunakan dalam penelitian ini adalah teknik triangulasi yaitu sebuah teknik pengumpulan data yang bersifat menggabungkan dari berbagai teknik pengumpulan data dan sumber data. Bila peneliti melakukan pengumpulan data dengan triangulasi, maka sebenarnya peneliti sekaligus menguji kredibilitas data. Adapun teknik pengumpulan data yang digunakan adalah observasi non partisipatif, wawancara mendalam (in depth interview) dan dokumentasi untuk sumber data yang sama serempak serta focus group discussion (FGD).

\section{HASIL DAN PEMBAHASAN}

Desa Talun yang terletak di Kabupaten Klaten, Provinsi Jawa Tengah. Luas wilayah desa Talun yaitu 15.315 Ha dengan batas utara berbatasan desa Panggang, batas selatan dengan desa Kendal Sari, batas timur berbatasan dengan Desa Bawukan dan batas utara berbatasan dengan desa Ngemplak seneng.

Desa Talun memiliki 10 dusun yang terbagi menjadi 21 RT dan 10 RW. Hasil pendataan tahun 2008 menunjukan 1075 penduduk berjenis kelamin laki-laki dan 1103 berjenis kelamin perempuan. Agama Islam paling banyak dianut oleh masyarakat, dengan pekerjaan sebagian besar adalah buruh pasir, peternak sapi dan banyak orang yang belum bermata pencaharian. Tingkat pendidikan masyarakat ratarata sampai pendidikan SMP.

Fasilitas kesehatan di desa Talun terdiri dari 1 Poskesdes, 1 Bidan desa, 5 Posyandu balita dan 1 Posyandu lansia. Fasilitas pendidikan terdiri dari 2 TK dan 2 SD.

Narasumber penelitian ini sebanyak 19 orang dengan karakteristik yang sudah dijelaskan sebelumnya. Narasumber yang ada terbagi menjadi 
2 yaitu yang diwawancarai dan sebagai anggota dalam FGD / Focus Group Discussion.

\section{A. Pengetahuan Surveilans Kese- hatan}

Masyarakat sebagian besar belum tahu istilah surveilans atau sistem pemantauan dan pelaporan penyakit, hal ini karena kurangnya sosialisasi kepada masyarakat dan kurangnya pemahaman masyarakat terkait penyakit-penyakit tertentu. Dalam hal pelaksanaan masyarakat sudah sedikit mengerjakannya tapi masih tidak terkordinir masih perlu ditingkatkan lagi.

Diawali dengan pertanyaan “ apa yang anda ketahui tentang Surveilans atau pemantauan dan pelaporan penyakit?", beberapa narasumber mengutarakan :

"Belum... Belum... belum pernah ya... Kayaknya belum... belum ini, Cuma kemaren setau saya itu pun baru sepengetahuan saya kemaren Cuma waktu gencar-gencarnya ada Flu burung itu aja mungkin kalo ada hewannya yang mati mendadak setelah makan itu nanti dilaporkan." (N7, 571583)

Dari pernyataan narasumber, narasumber tidak mengetahui tentang sistem surveilans kesehatan atau pemantauan dan pelaporan penyakit berbasis masyarakat, namun masyarakat hanya mengetahui penyakitpenyakit yang perlu dilaporkan tetapi prosesnya seperti apa masyarakat tidak mengetahuinya, hal ini dikarenakan masyarakat pernah mendapatkan penyuluhan dibalai desa dan oleh ibuibu PKK tentang penyakit-penyakit tertentu yang mudah menular dan banyak di masyarakat untuk dilaporkan kepada petugas kesehatan, untuk mekanisme atau sistem surveilansnya sendiri masyarakat belum pernah mendapatkan penyuluhan tentang hal itu.

Sama halnya pada penelitian yang dilakukan Direktorat Kesehatan dan Gizi Masyarakat (2006) pemahaman aparat (petugas kesehatan) terhadap program surveilans cukup baik, Akan tetapi pemahaman tentang surveilans dan penanggulangan KLB masih belum sama. Upaya yang dilakukan Dinas Kesehatan Propinsi maupun kabupaten/kota dalam rangka peningkatan kemampuan adalah pembinaan teknis, mengadakan pertemuan/ lokakarya, rakor dan melakukan berbagai pelatihan di bidang surveilans maupun penanggulangan penyakit. Selain pelatihan formal, pengetahuan tim pada umumnya dipenuhi dari pengalaman lapangan dalam penanganan P2M. Penelitian operasional surveilans kesehatan keluarga Pusat Manajemen Pelayanan Kesehatan Fakultas Kedokteran Universitas Gadjah Mada (PMPK FK UGM) bekerja sama dengan Satuan Kerja Direktorat Jenderal Bina Kesehatan Masyarakat The First Decentralized Health Services Project (DHS1 ADB/Loan No.1810-INO) melakukan 
peningkatkan pengetahuan tentang surveilans dengan melakukan penyusunan modul surveilans kesehatan keluarga dan pelaksanaan program pelatihan (Direktorat Kesehatan dan Gizi Masyarakat, 2006).

\section{B. Dukungan Surveilans Kesehatan}

Pelaksanaan surveilans berbasis masyarakat membutuhkan dukungan baik segi sumber daya manusia ataupun dari segi pembiayaan. Di desa Talun tidak ada dukungan biaya untuk kelancaran program surveilans berbasis masyarakat, seperti yang diungkapkan oleh narasumber dibawah ini;

"Kalo pembiayaan khusus, khusus untuk surveilans kayanya itu belum ada. Dikhususkan itu belum ada." (N4, 918-920)

Narasumber dari petugas puskesmas menyatakan puskesmas melakukan tugas surveilans menggunakan dana dari Biaya Operasional Ksehatan (BOK) dari dinas karena memang untuk tugas surveilans puskesmas adalah program institusional dan tidak berkaitan dengan pembiyaan surveilans berbasis masyarakat.

Penelitian yang dilakukan Direktorat Kesehatan dan Gizi Masyarakat (2006) dilaksanakan di 6 (enam) propinsi terpilih yang ditentukan berdasarkan karakteristik frekuensi terjadinya kejadian penyakit menular dari kelompok propinsi di Indonesia Bagian Barat, Tengah dan Timur sama seperti yang terjadi di daerah Klaten yaitu puskesmas tidak memiliki alokasi dana khusus untuk kegiatan surveilans. Dana operasional untuk surveilans selain bersumber dari dana operasional umum (BOK) juga memanfaatkan dana JPK-MM. Respon oleh pemerintah pusat dari kegiatan surveilans lebih banyak ke pencegahan tersier yang mempunyai risiko keterlambatan (Direktorat Kesehatan dan Gizi Masyarakat, 2006).

Sebagian masyarakat peduli terhadap kesehatan lingkungan yang menandakan bahwa masyarakat memiliki potensi untuk menjalankan program surveilans kesehatan berbasis masyarakat. Seperti diungkapkan narasumber dibawah ini:

"Iya kadernya kan ngajak kalo misalnya yang tua-tua itu yang sakit itu nanti... kita diundangan suru datang ke posyandu lansia gitu." (N10, 272-274)

Masyarakat memiliki potensi untuk menjalankan program surveilans di masyarakat bisa dilihat dari keaktifan kader, aktif dalam kegiatan, mengikuti dan menjalankan program posyandu, hanya saja yang perlu diperbaiki adalah pengetahuan masyarakat dan kordinasi untuk menjalankan kegiatan surveilans terutama dari puskesmas sebagai pendamping masyarakat dan berfungsi sebagai lembaga pemberdaya masyarakat.

Hasil studi di Dinas Kesehatan Kota Yogyakarta tentang sistem 
surveilans menunjukkan bahwa data dari bidan dan masyarakat dikumpulkan ke bidang pelayanan kesehatan masyarakat dipuskesmas. Berbeda dengan di Desa Talun masyarakat belum melaporkan data secara khusus ke puskesmas karena kurangnya pengetahuan masyarakat. Hasil studi Dinkes kota Yogyakarta juga menyatakan di tingkat puskesmas selama ini belum dilakukan analisis data. Salah satu penyebab adalah belum tersedianya SDM untuk bidang surveilans. Data yang telah dikumpulkan di puskesmas kemudian diserahkan ke bidang pelayanan kesehatan masyarakat di Dinas Kesehatan Kota Yogyakarta. Tidak adanya tim yang menangani data di tingkat puskesmas, menyebabkan data yang dikumpulkan tidak termonitor. Hal ini yang menyebabkan terjadinya perbedaan data di antara program-program dan bidang-bidang yang berjalan di Dinas Kesehatan Kota Yogyakarta (Trisnantoro dkk, 2007). Kejadian seperti ini juga terjadi di puskesmas Kemalang kabupaten Klaten tempat dimana dilakukannya penelitian ini.

\section{Pelaksanaan Surveilans}

Pelaksanaan surveilans berbasis masyarakat adalah salah satu indikator desa siaga, dalam pelaksanaannya pun tidak terlepas dari kegiatan desa siaga yang lainnya, seperti yang diungkapan narasumber berikut:
"Owh ada... ada, biasane yang bertanggung jawab biasane nyatet itusing aktif forum kesehatan desa tu sebagian eneng ada kui sing rodo biasane nyatet anu... ini kader KB." (N5, 297-301)

Sebagian besar responden menyatakan pelaksanaan program surveilans belum maksimal karena masyarakat masih perlu didampingi dari pihak terkait khususnya puskesmas, sementara dari puskesmas sendiri permasalahan yang dihadapi sangat kompleks, dan tidak adanya dukungan dana untuk puskesmas untuk mendampingi masyarakat menjalankan program surveilans berbasis masyarakat. Kegiatan pelaksanaan surveilans menurut narasumber dibarengi dengan kegiatan desa siaga lainnya yaitu posyandu dimana fungsi posyandu sekaligus juga sebagai pematauan permasalahan kesehatan yang ada di masyarakat, dan sekaligus dibarengi dengan pencatatan KB.

Penelitian yang dilakuakan Badan Perencanaan Pembangunan Nasional (2006) di Jawa Barat pelaksanaan program surveilans belum optimal dilakukan oleh kader dengan alasan terbatasnya dana operasional, kesibukan kader, dan tidak seimbangnya jumlah kader dengan cakupan daerah yang harus diselidiki. Di Jawa Timur penemuan kasus dilaksanakan secara bekerjasama dengan masyarakat, dokter, praktek swasta, bidan, perawat, dukun bayi dan kendaraan kesehatan. 
Di kabupaten Lombok Tengah, surveilans pengamatan bebas jentik dilakukan oleh murid-murid sekolah telah terbukti cukup efektif dan dapat direflikasi di daerah lain. Pada pelaksanaan di Puskesmas, dukungan dana surveilans tertolong oleh adanya subsidi dari Askeskin, terutama untuk insentif tenaga kesehatan dan kader ((Direktorat Kesehatan dan Gizi Masyarakat, 2006).

Menurut Depkes (2007) Berdasar pengamatan peneliti kegiatan surveilans di desa Talun belum begitu berjalan, karena kurangnya sosialisasi yang berakibat kepada kurangnya pengetahuan masyarakat, dan di posyandu masyarakat hanya menjalankan fungsi posyandu sebaagaimana mestinya (Depkes RI, 2007). Senada dengan apa yang disamapaikan narasumber:

"Saya kira masih sulit, masih belum belum begitu jalan untuk pelaporanpelaporan termasuk penyakit-penyakit kaya gitu." (N7, 615-621)

Sebagian besar responden menyatakan belum ada sosialisasi khusus untuk system pelaksanaan surveilans di masyarakat, hanya dimasukan secara tersirat dalam penyuluhan-penyuluhan tentang penyakit-penyakit yang banyak di masyarakat sedangkan surveilas yang dilakukan bidan desa hanya terbatas pada pasien yang memang memeriksakan diri keposkesdes sementara bidan desa diposkesdes hanya sekitar dua sampai tiga jam setiap harinya. Penelitian Direktorat Kesehatan dan Gizi Masyarakat (2006) di Propinsi Sulawesi Selatan penyuluhan dan sosialisasi surveilans dilakukan secara intensif melalui media cetak dan elektronik ((Direktorat Kesehatan dan Gizi Masyarakat, 2006; Trisnantoro dkk, 2007).

\section{Hambatan Surveilans Kesehatan}

Dalam pelaksanaa program surveilans berbasis masyarakat menemui banyak hambatan terutama hambatan sosialisasi dari pihak terkait yang menyebabkan kurangnya pegetahuan masyarakat terhadap permasalahan yang ada di lingkungannya, seperti yang diungkapkan

"Ya mungkin kurang pengetahuan masyarakat, tentang itu berbagai macam penyakitnya". (N4, 1019-1029)

Sebagian besar responden berpendapat kurang seriusnya puskesmas dalam menangani desa siaga juga berdampak pada kurang optimalnya kegiatan surveilans berbasis masyarakat ini. Hal ini serupa yang terjadi pada penelitian yang dilakukan Trisnantoro dkk (2007) di Nangroe Aceh Darussalam dan di Daerah Istimewa Yogyakarta bahwa pemda merasa bahwa urusan surveilans adalah urusan pemerintah pusat, sehingga pemda tidak memprioritaskan program surveilans dan menganggap 
surveilans tidak terlalu penting. Persepsi pemda seperti ini yang menjadikan alokasi anggaran untuk pelaksanaan kegiatan surveilans sangat rendah (Trisnantoro dkk, 2007).

Penelitian yang dilakukan Badan Perencanaan Pembangunan Nasional (2006) kendala yang masih terjadi adalah kurang atau tidak adanya koordinasi dari instansi-instansi yang seharusnya terkait. Kebijakan desentralisasi juga berpengaruh terhadap koordinasi antara pusat dan daerah dalam kewenangan penanganan sistem surveilans. Kebijakan tersebut terkait dengan anggaran kesehatan untuk pencegahan serta pemberantasan penyakit menular, yang memang membutuhkan biaya sangat tinggi. Dengan adanya kewenangan penanganan yang didaerahkan terkadang menyulitkan dalam koordinasi penganggaran. Pihak daerah seringkali kewalahan dalam penyediaan biaya operasional penanganan penyakit karena keterbatasan sumberdaya, baik dana maupun tenaga. Disisi lain adanya desentralisasi sumberdaya yang dimiliki, pemerintah pusat mengalami kendala dalam pendistribusiannya ke daerah. Hal ini menjadi faktor penghambat praktek penanganan kasus di lapangan (Direktorat Kesehatan dan Gizi Masyarakat, 2006 ).

\section{E. Pengetahuan tentang Kesiap- siagaan Masyarakat}

Pemahaman sebagian besar narasumber mengenai kesiapsiagaan dan penanggulangan kegawatdaruratan dan bencana berbasis masyarakat adalah kesiapsiagaan menghadapai bencana, hal ini dapat terjadi karena kurangnya sosialisasi. Menurut Depkes RI (2007) Kesiapsiagaan dan penanggulangan kegawatdaruratan dan bencana berbasis masyarakat adalah upaya yang dilakukan masyarakat untuk mengantisipasi terjadinya kegawatdaruratan sehari-hari dan bencana, melalui langkah-langkah yang tepat guna dan berdaya guna (Depkes RI, 2007).

Beberapa pernyataan narasumber terkait kesiapsiagaan dan penanggulangan kegawatdaruratan dan bencana berbasis masyarakat :

"Taunya kalo masyarakat itu kalo siaga-siaga itu ya taunya ada bencana gitu mas...Kalo menurut saya ya kesiapsiagaan itu ngga cuman kalo ada bencana tapi yo setiap ada kejadian apapun." (N10, 308-316)

Narasumber sebagian besar memahami program kesiapsiagaan dan penanggulangan kegawatdaruratan dan bencana yaitu terkait bencana gunung merapi karena memang letak desa Talun yang berada di lereng Merapi yang sedikit banyak berpengaruh terhadap pemahaman masyarakat tentang kesiapsiagaan serta kurangnya pendampingan dari stakeholder terkait.

Dalam penelitian Permanasari (2010) juga diungkapkan masyarakat 
sudah mengetahui tentang kesiapsiagaan dalam meghadapi bencana khususnya bencana gunung merapi, yang intinya adalah masyarakat tahu dan sigap dalam menghadapi yang akan terjadi maupun saat terjadi (Permanasari, 2010).

\section{F. Dukungan Kesiapsiagaan Masya- rakat}

Pembiyaan pelaksanaan program kesiapsiagaan masyarakat dalam desa siaga memerlukan banyak biaya karena berbagai kegiatan yang harus dilakukan secara berkelanjutan. Biaya yang digunakan tidak hanya berasal dari pemerintah namun bisa juga melalui sumber-sumber lain seperti dana swadaya masyarakat dan dana swasta seperti LSM.

"Dari sebagian kas kampung, terus untuk yang merasa punya kendaraan baik truck maupun roda empat bisa menyumbangkan kendaraannya untuk mengangkut itu kan, demikian." (N6, 428-434)

Sebagian besar narasumber berpendapat dana untuk kesiapsiagaan masyarakat yang secara khusus diaggarkan belum ada baik dari desa maupun dari pemerintah, pada saat erupsi merapi dana yang masuk adalah berupa dana bantuan untuk bencana alam, dana nya bersumber dari berbagai instansi dan LSM. Kegiatan kegiatan masyarakat dananya sebagian besar diambil dari kas desa dan iuran warga-warga yang peduli. Penelitian yang dilakukan Permanasari (2010) tentang kesiapsiagaan masyarakat dalam megahadapi erupsi merapi dalam desa siaga di Desa Umbulharjo terdapat 3 sumber dana yang mendukung program kesiapsiagaan masyarakat yaitu dari pemerintah melalui Dinas Kesehatan, Pemerintah Kabupaten Sleman, bantuan pemerintah desa dan swadaya masyarakat. Dana dari dinas kesehatan diberikan satu tahun sekali (Permanasari, 2010).

Dukungan dalam pelaksanaan program kesiapsiaaan masyarakat didapatkan juga dari semua lapisan masyarakat, baik dari instansi terkait seperti kepala desa, puskesmas, kecamatan, karang taruna, tokoh masyarakat dan masyarakat itu sendiri. Masyarakat desa talun juga mempunyai potensi untuk mengembangkan program kesiapsiagaanmasayarakat yaitu dengan membentuk Fortasita. Ini sesuai dengan yang disampaikan oleh narasumber:

“Kalo saya tu... kalo misalnya bencana terhadap opo misal gempa gitu kan disekolah-sekolah gitu banyak diadakan latihan-latihan juga dari anak-anak." (N10, 344-347)

Sebagian besar narasumber berpendapat desa berkordinasi lintas sektor mulai dari tokoh agama sampai dengan karang taruna untuk menjalankan program kesiapsiagaan masyarakat. Forum-forum pendukung 
kegiatan kesiapsiagaan masyaraat juga dibentukm oleh masyarakat yaitu Fortasita (Forum Tanggap Siaga Talun). Latar belakang terbentuknya Fortasita yaitu karena adanya warga desa lain (Bale rante) yang berdekatan dengan desa Talun meninggal dunia karena terkena awan panas yang disebabkan ketidak tahuan warga harus kemana dan berbuat apa ketika bencana terjadi. Sama halnya pada penelitian yang dilakukan Permanasari (2010) masyarakat dari berbagai lapisan medukung pelaksanaan program kesiapsiagaan masyarakat dilihat dari dukungan pihak promosi kesehatan yang memberikan penyuluhan, pelatihan dan pembinaan. Bidan desa yang sebagai koordinator desa siaga memberikan dukungan tidak terlepas dari peran kader yang ada, seperti melakukan posyandu dan mengarahkan masyarakat dengan terjun langsung ke masyarakat.

\section{G. Pelaksanaan Kesiapsiagaan Ma- syarakat}

Kesiapsiagaan masyarakat harus dilaksanakan secara berkesinambungan dan saling mendukung antara masyarakat dan tenaga kesehatan. Masing-masing unsur harus berperan dengan pembagian tugas masingmasing (Depkes RI, 2007). Kegiatan kesiapsiagaan masyarakat seperti diungkapkan narasumber dibawah ini:

"E... Diajalankan tapi ya... itu sebatas mengadakan kegiatan.. ee termasuk pelatihan-pelatihan.. dan sebagainya... pertemuan di balai desa dan sebagainya... baru itu saja." (N6, 439443)

Pelaksanaan kegaiatan menurut narasumber yaitu berupa pelatihan gabungan, pemberdayaan kader untuk melakukan penyuluhan dampak erupsi merapi dan cara menanganinya seperti penyakit ISPA yang cukup banyak pasca erupsi, merumuskan alur evakuasi dan menentukan titik kumpul dan membahas sarana komunikasi. Narasumber juga menyatakan biasanya dalam pelaksanaannya bekerjasama dengan PMI, Puskesmas, Rumah Sakit yang dikordinatori oleh PMI. Pada penelitian Permanasari (2010) pelaksanaan kegiatan kesiapsiagaan masyarakat sudah berjalan dengan sangat baik, mulai dari pelaksanaan pelatihan dan simulasi yang diadakan oleh oraganisasi desa siaga sendiri ataupun dari desa, terkadang dari organisasi desa siaga mengundang dari puskesmas untuk memberikan penyuluhan dan pelatihan, materi-materi yang disampaikan terkait pertolongan pertama dan materi-materi untuk mengurangi resiko-resiko yang terjadi pada saat bencana merapi.

Koordinasi yang terjadi antara masyarakat, kader, bidan, puskesmas dan stakeholder lainnya berjalan dengan baik, seperti diungkapkan oleh beberapa narasumber sebagai berikut: 
"Nah ini kalo bicara kegawatdaruratan bencana ini bicara tim, tim itu melibatkan sektor kepolisian, koramil TNI, kecamatan dan kami." (N1, 634637)

Kordinasi yang dilakukan di Desa Talun sudah cukup baik karena dalam pelaksanaan program kesiapsiagaan dan penanggulangan bencana bekerja sama dengan semua pihak yang ada seperti bidan desa, kader, pemuda, perangkat desa tokoh masyarakat dan masyarakat itu sendiri. Pada penelitian Permanasari (2010) juga didapatkan hal yang sama, pelaksanaan kegiatan kesiapsiagaan masyarakat bekerja sama dengan segala elemen yang ada seperti bidan desa, kader, perangkat desa, tokoh masyarakat, masyarakat dan kepala dukuh.

Target dan proses pencapaian yang dilakukan masyarakat yaitu dengan memperbaiki komunikasi melalui sarana komunikasi yang ada seperti HT dan Horn mesjid, untuk mengkomunikasikan dan mengkordinasikan warga, bekerjasama dengan LSM atau mahsiswa, dan para pemuda melakukan pematauan merapi secara visual dimana target dari program kesiapsiagaan masyarakat adalah masyarakat menjadi garda terdepan dalam pemecahan masalah baik itu bencana dan kesehatan dan ketika bencana untuk meminimalisir korban. Seperti yang diungkapkan narasumber dibawah ini:
"Targetnya kan tidak ada korban ya... dari tanggap darurat itu tidak ada korban, tapi kenyataannya sulit juga, memang disini ngga ada korban, cuma satu di Balerante itu, karena memang kena awan panas dan ditingal itu" (N3, 882-887)

Proses pencapaian yang dilakukan masyarakat Desa Talun dalam program kesiapsiagaan masyarakat pasca erupsi merapi cukup baik, dilihat dari berbagai upaya penanggulangan yang dilakukan dan masyarakat sudah mulai berpikir akan dampak merapi karena erupsi merapi adalah siklus pasti akan datang lagi seperti pembentukan forum fortasita serta keterlibatan seluruh komponen masyarakat akan semakin mensinergikan sistem kesiapsiagaan maysarakat.

\section{H. Hambatan Kesiapsiagaan Masya- rakat}

Dalam pelaksanaannya program kesiapsiagaan masyarakat menemukan berbagai macam kendala diantaranya yaitu kurangnya pengetahuan warga, ada beberapa warga yang tidak patuh terhadap instruksi pemerintah terkait, kepengurusan program kesiapsiagaan masyarakat (Fortasita) yang minim dan terbentur masalah ekonomi, geografis juga menjadi kendala yaitu jalan menuju desa Talun rusak serta adanya mitosmitos di masyarakat yang beranggapan bahwa desa Talun tidak mungkin terkena dampak erupsi. Seperti yang disampaikan oleh narasumber dibawah ini: 
"Salah satu adalah yang menghambat dari belum erupsi dan sudah erupsi itu karena orang belum mengetahui bagaimana bahayanya merapi, jadi yang lari ya yang mau saja, terus dampaknya macem-macem seperti yang sudah saya ceritakan." (N8, 307-312)

Hal lain yang menjadi kendala yaitu berupa armada yang dimiliki masyarakat yang tidak selalu stand by dan belum ditentukan secara khusus kendaraan milik siapa yang akan digunakan untuk keperluan program kesiapsiagaan masyarakat serta yang menjadi rencana warga dan belum terlaksana yaitu melakukan pengecekan golongan darah guna pendataan dan pertolongan jika ada warga yang memerlukan darah. Hal ini terjadi juga pada forum desa siaga di desa Rasau kecamatan Pamenang kabupaten Merangin propinsi Jambi (2007) yang menjadi kendala dalam program kesiapsiagaan yaitu berupa kesulitan mencari armada yang pas jadwalnya namun si pemilik sedang tidak ada atau ada kepentingan pribadi sehingga terjadi kelambatan pelayanan karena harus mencari pengganti atau urutan berikutnya dan belum semua masyarakat / anggota memeriksakan golongan darah (Laporan Hasil dan Proker 2008).

\section{Pengetahuan Desa Siaga}

Narasumber diharapkan dapat memberikan pandangannya terhadap pelaksanaan Desa Siaga dengan baik, sesuai dengan tujuan penelitian yang ingin dicapai. Pernyataan narasumber mengenai arti desa siaga.

“... ya kalau menurut saya desa siaga itu adalah desa yang siap menghadapi terhadap sesuatu kejadian".

Dari pernyataan nara sumber sebagian besar sudah mengetahui tentang desa siaga, yang intinya adalah suatu desa yang mandiri, mengetahui dan tanggap terhadap semua masalah yang akan dihadapi dan sudah menyiapkan jalan keluar khususnya di bidang kesehatan sesuai dengan yang dikonsepkan Departemen Kesehatan Republik Indonsia. Pernyataan narasumber sesuai dengan tujuan yang ingin dicapai oleh Desa Siaga yaitu dapat terwujudnya masyarakat yang sehat, peduli dan tanggap terhadap permasalahan kesehatan di wilayahnya.

Dalam penelitian Permanasari (2010), sebagian besar masyarakat tidak mengetahui istilah desa siaga tapi mereka dapat menyimpulkan arti desa siaga serta tahu tentang kegiatan yang dilakukan oleh puskesmas, bidan desa atau kader, seperti kegiatan posandu yang diadakan tiap bulan, pengetahuan tentang gizi, kesehatan ibu dan anak.

\section{J. Sosialisasi Desa Siaga}

Pada dasarnya sosialisasi desa siaga di desa Talun bisa dioptimalkan mengingat banyaknya pertemuanpertemuan yang dilakukan warga, 
mulai dari pertemuan arisan dan sebagainya. Sosialisasi di desa Talun sudah dilakukan dengan mengundang seluruh komponen masyarakat yaitu aparat desa, kader kesehatan, tokoh masyarakat, pemuda dan warga. Tidak adanya tindak lanjut dari sosialisasi desa siaga ini membuat pemahaman masyarakat tidak menyeluruh sementara masyarakat masih membutuhkan pembinaan. Sosialisasi melalui media elektronik berupa iklan dan himbauan oleh Dinas Kesehatan Klaten, serta informasi melalui media cetak oleh Pemerintah Kabupaten Klaten dirasa perlu diupayakan.

"Iya menyediakan sosialisasi khusus tentang konsep Desa Siaga tersebut malah dua kali mungkin satu Desa itu, tapi 2009 ada sama 2010 keliatannya itu kalo ngga salah 2008 sampai 2010." (N2, 185-189)

Pada penelitian Permanasari (2010) sosialisasi dilakukan oleh petugas puskesmas langsung ke masyarakat atau jika tidak memungkinkan hanya kadernya saja dan kemudian kader yang terjun langsung ke masyarakat karena didukung dengan kader yang ada di setiap dusun. Tokoh masyarakat juga dilibatkan dalam sosialisasi ini.

Tindak lanjut dari sebuah sosialisasi sangat diperlukan guna kepentingan evaluasi dan monitoring. Berikut pernyataannarasumber terkait tindak lanjut dari sosialisasi desa siaga:
"Belum, harusnya ada memang itu harusnya sudah bener-bener terbentuk atau belom itu harusnya ada, tapi untuk saat ini sampai saat ini belom..." (N2, 190-196)

Sosialisasi desa siaga di desa Talun dilakukan pada awal pembentukan desa siaga sekitar tahun 2008 oleh kepala puskesmas, petugas puskesmas, kepala Desa, Ketua RT, pemuda dan beberapa warga yang mempunyai pengetahuan tentang desa siaga. Pada forum desa siaga di desa Rasau kecamatan Pamenang kabupaten Merangin propinsi Jambi (2007) dibentuk adanya divisi humas dan umum yang salah satu tugasnya untuk mensosialisasikan hasil rapat forum desa siaga kepada pemerintah desa, puskesmas dan kecamatan.

Dalam penelitian Patramanda (2010) sosialisasi desa siaga menjadi lebih efektif dan efisien dengan dilakukannya berbagai upaya sosialisasi melalui media elektronik, media cetak oleh dinas kesehatan setempat dan diadakannya pertemuan di tingkat desa yang mengundang seluruh komponen masyarakat yang nantinya akan kembali ditindaklanjuti dengan melakukan sosialisasi ditingkat dusun yang dilakukan oleh kader. Poster dan leaflet juga turut digunakan sebagai sarana sosialisasi oleh Puskesmas. Ini menggambarkan peran aktif kader dan Puskesmas dalam melakukan sosialisasi ke masyarakat. Hal ini yang belum dilakukan oleh Dinas kesehatan Klaten, 
Puskesmas kemalang dan kader kesehatan desa Talun (Patramanda, 2010).

\section{K. Dukungan terhadap Desa Siaga}

Demi terlaksananya program Desa Siaga membutuhkan dukungan baik dari sumber daya manusia yang ada maupun pembiayaan. Pembiayaan pelaksanaan desa siaga tidak sedikit karena berbagai kegiatan harus dilakukan secara berkelanjutan. Biaya yang digunakan tidak hanya berasal dari pemerintah namun juga ada sumber-sumber lain, baik dari masyarakat ataupun swasta, meskipun untuk Desa Talun masih tergantung dana pemerintah karena sosial ekonomi masyarakat yang kurang.

"Desa siaga itu kemarin dalam pembentukan memang, di...diapa, diini, di fasilitasi pendanaannya dari APBD insyaallah klo gak salah. Cuma kemarin yang yang yang ini, yang mengurusi ini kan promkes,...." (N1, 87-91)

Kebijakan Depkes (2006) Anggaran berasal dari APBN yang dialokasikan pada DIPA Satker Sekretariat Ditjen Bina Kesehatan Masyarakat dengan jenis kegiatan Dana Bantuan Sosial. Namun dari pengamatan peneliti dana-dana untuk pelaksanaan desa siaga belum terkordinir dengan baik dan tidak ada dana khusus untuk desa siaga. Pendanaan yang digunakan berasal dari pemerintah sebenarnya sudah mencukupi kegiatan atau pelatihan-pelatihan yang dilakukan dalam rangka memberdayakan masyarakat menuju desa siaga (Permanasari, 2010; Patramanda, 2010).

Dukungan dalam pelaksanaan program Desa Siaga juga didapatkan dari semua lapisan masyarakat, baik dari instansi terkait seperti kepala desa, puskesmas dan juga dari tokoh masyarakat serta masyarakat sendiri sampai dengan partai politik, ini senada dengan yang diungkapkan narasumber :

"Dukungan kita sebatas anu ya.. pembinaan.. pendampingan untuk dana tidak.. tidak banyak membantu." (N3, 236-238)

Dari pengamatan peneliti dukungan masyarakat juga sangat baik, dengan seringnya mengikuti kegiatan posyandu yang ada, berperan aktif dalam kegiatan, bekerjasama dengan kader dalam memeberikan informasi untuk pendataan dan lainnya. Dukungan dari semua elemen masyarakat sangat diperlukan guna tercapainya keberhasilan kegiatan dsa siaga yang nantinya akan menentukan keberhasilan dari pelaksanaan desa siaga itu sendiri. Masyarakat biasanya tidak tahu bahwa program-program kesehatan yang mereka kerjakan adalah program desa siaga.

Dukungan yang diberikan masyarakat dan pihak-pihak terkait menunjukan bahwa desa Talun sebenarnya berpotensi untuk mengembangkan desa siaga karena warga serta 
karang taruna sebenarnya siap untuk menjalankan fungsinya dengan baik. Selain itu juga sudah ada faktor lain yang mendukung jalannya desa siaga yaitu kader kesehatan serta adanya dukungan dari perangkat desa. Seperti yang diungkapkan dibawah ini :

"Ya potensinya ya kadernya itu.. kader kesehatannya itu... kemudian pokoe dukungan dari perangkat itu.. potensipotensi.. kader posyandu.. kader kesehatan.. sama dukungan dari perangkat desa itu". (N4, 501-506)

Potensi masyarakat tersebut dibenturkan dengan kurang optimalnya pendampingan dan pembinaan oleh puskesmas atau dinas kesehatan hal ini membuat kegiatan desa siaga di desa Talun tidak berkembang secara maksimal. Adanya kesalahpahaman cara pandang masyarakat dan pihak pendamping, dalam hal ini puskesmas bahwa pemberdayaan masyarakat bertumpu pada bantuan dan uluran dana dari pemerintah baik pusat maupun daerah, seperti pernyataan narasumber dibawah ini :

"kalau dari pendanaan sendiri ya gak mungkin, heheh ya mungkin dari pemerintah, minta bantuan pemerintah..." (N18, 236-238)

Pendanaan forum desa siaga di desa Rasau kecamatan Pamenang kabupaten Merangin propinsi Jambi (2007) bersumber dari tabungan ibu bersalin (Tabulin), dana sehat untuk pengobatan rawat jalan dan Dana Sosial yang mencakup pelayanan Donor Darah dan Trasportasi (Ambulance Desa).

\section{Pelaksanaan Desa Siaga}

Pelaksanaan desa siaga di desa Talun sudah cukup baik. Hal ini terlihat dari kegiatan-kegiatan yang dilakukan masyarakat, koordinasi masyarakat, kesadaran masyarakat yang mulai muncul, indikator kesehatan ibu dan anak serta kebiasaan MCK menjadi lebih baik.

"Desa siaga ya ini, paling ya..ini..untuk..paling rapat-rapat, paling ada pertemuan-pertemuan, teruss membahas permasalahanpermasalahan di desa siaga" (N1, 98101)

Penelitian Hermansyah (2008) tentang persepsi stakeholder terhadap pelaksanaan desa siaga di Kabupaten Sambas, menunjukkan kegiatan yang dilaksanakan dalam desa siaga meliputi pelaksanaan posyandu, poskesdes, dana tabulin, ambulan desa, kelompok donor darah, penggalangan dana masyarakat, sosialisasi dan penyuluhan, surveilans sederhana, pembentukan tim siaga bencana, kebersihan lingkungan serta pencatatan dan pelaporan.

Kegiatan desa siaga menurut narasumber antara lain meliputi tentang forum masyarakat yang membahas permasalahan kesehatan, 
pengecekan golongan darah untuk mengantisipasi kehamilan resiko tinggi, keterlibatan tenaga medis dan kader posyandu, membuat gardu pandang, menentukan jalur evakuasi, menydiakan alat transportasi jika suatu saat dibutuhkan, posyandu, makanan bergizi (kadarzi) dan adanya iuran warga. Kegiatan yang dilakukan oleh warga sesuai dengan indikatorindikator pencapaian desa siaga seperti yang telah ditetapkan oleh Depkes RI (Depkes RI, 2006).

Kordinasi desa siaga antara masyarakat, kader, bidan, puskesmas dan stakeholder lainnya berajalan dengan baik seperti yang diungkapkan beberapa narasumber sebagai berikut :

"Bisa melibatkan semua elemen masyarakat semua terutama pemudanya nanti sebagai eksekutor." (N7, 294-296)

Koordinasi di Desa Talun sudah cukup baik dilihat dari pernyataan narasumber diatas sesuai dengan sasaran pengembangan desa siaga oleh Depkes RI tahun 2007.

Pada penelitian Hermansyah (2008) kordinasi yang dilakukan yaitu dengan dinas kesehatan kabupaten, aparat pemerintah desa dan masyarakat. Peran pemerintah daerah dalam mendukung pelaksanaan desa siaga dirasa masih kurang di Kabupaten Sambas, sehingga dinas kesehatan perlu terus meningkatkan sosialisasi dan advokasi tentang desa siaga kepada pemerintah daerah maupun sektor terkait.

Keberhasilan pengembangan dari pelaksanaan desa siaga bisa ditentukan dari empat indikator yaitu; indikator masukan, indikator proses, indikator keluaran dan indikator dampak. Senada dengan pernyataan narasumber:

"Yo dulu...Yoada mas... kalo dulu kan belum tau kalo ada yang sakit itu harus anu harus diajak begini-begini begitu." (N10, 293-299)

Sebagian besar narasumber menyatakan selain dari FKD masyarakat melalui posyandu juga sudah mandiri, adanya PMT, BGM dan BGT kader posyandu sudah sangat paham dan sudah bisa memberikan edukasi kepada orang tua yang mempunyai balita. Kader posyandu juga dapat memberikan edukasi terkait kesadaran lingkungan jika BAB harus di MCK tidak di kebun-kebun, dan memberikan informasi mengenai air bersih untuk PAH.

\section{Hambatan Pelaksanaan Desa Siaga}

Hal utama yang menjadi terhambatnya pelaksanaan desa siaga di desa Talun adalah masalah pendanaan yang diikuti dengan permasalahan jarak puskesmas dan desa Talun yang jauh sehingga menyulitkan pendampingan dan pengontrolan, sosial ekonomi budaya masyarakat yang rendah, 
tingkat pemahaman dan tingkat pendidikan, aktivitas warga desa Talun yang rata-rata sebagai penambang pasir serta keseriusan stakeholder untuk menindaklanjuti kebijakan desa siaga.

"Ooh faktor, kalau faktor, satu, kalau yang menghambat, kadang kurang pengetahuan, kesehatan atau apa.." $(N 8,285-287)$

Program-program dalam pelaksanaan desa siaga belum tercapai karena terkait dengan masalah pembiayaan yang menyebabkan kegiatan tidak bisa berjalan, padahal menurut petunjuk tenis yang ditetapkan oleh Ditjen Binkesmasseharusnya Pemda, Dinkes atau puskesmas mempunyai dana stimulansia untuk pemberdayaan masyarakat. Hal ini sebenarnya bisa diatasi ketika semua pihak yang terlibat dalam pelaksanaan desa siaga menjalin komunikasi, kordinasi dan konsolidasi (kerja sama) dengan baik.

\section{N. Harapan Masyarakat}

Dalam pelaksanaannya pelaksanaan desa siaga membutuhkan masukan dan saran agar dapat berjalan lebih baik untuk kedepannya. Beberapa narasumber menyampaikan saran dan tanggapan mereka terkait pelaksanaan desa siaga agar dapat tertata dengan baik dan berjalan dengan lancar.

"Ya anu mas, harapane ki yo baiknya di support Dana itu, entah itu dari
Kabupaten, dari Provinsi harapannya gitu, syukur dari pusat, sudah ada sendiri untuk kaitannya ke pos-pos itu, harapannya seperti itu." (N5, 367-372)

Dari pihak puskesmas menyatakan konsep desa siaga sangat baik sekali dalam meningkatkan derajat kesehatan masyarakat, hanya saja untuk tindak lanjut belum ada. Harapan dari puskesmas desa siaga bisa berjalan seperti apa yang sudah dikonsepkan, desa siaga bisa menjadi desa yang mandiri, karena pada kenyataannya di kecamatan Kemalang belum ada yang berjalan. Selain itu harapan masyarakat yaitu agar pembina desa bisa berdomisili di desa Talun agar lebih mudah menontrol keadaan dan permasalahan kesehatan yang ada di masyarakat, untuk desa Talun dalam pelaksanaan desa siaga adalah agar desa Talun dapat berjalan dengan mandiri.

\section{KESIMPULAN}

Pengetahuan masyarakat tentang desa siaga sudah cukup baik dilihat dari keikutsertaan dalam program-program desa siaga yang diberikan oleh puskesmas, posyandu, bidan desa atau kader dan masyarakat mengetahui tujuan dibentuknya desa siaga. Untuk pengetahuan kesiapsiagaan dan penanggulangan kegawatdaruratan dan bencana berbasis masyarakat masih menganggapnya itu adalah kesiapsiagaan terhadapa bencana saja dilihat dari apa yang masyarakat ketahui dan masyarakat 
lakukan. Untuk pengetahuan surveilans kesehatan berbasis masyarakat belum baik karena masih banyak masyarakat yang belum mengetahui tentang surveilans berbasis masyarakat.

Dukungan Pelaksanaan desa siaga belum terlalu baik, dilihat dari pembiayaan yang belum terkordinasi dengan baik. Dukungan untuk kesiapsiagaan dan penanggulangan kegawatdaruratan dan bencana berbasis masyarakat sudah cukup baik dilihat dari pembiayaan, pelatihan dan dukungan dari semua stakeholder, pemerintah relawan dan LSM-LSM terkait serta masyarakat. Dukungan terhadap program surveilans kesehatan berbasis masyarakat masih kurang dilihat dari tidak adanya dana dan kurangnya sosialisasi.

Pelaksanaan Desa Siaga dan Kesiapsiagaa masyarakat mulai dari kegiatan dan pihak yang terlibat, sarana yang ada proses pencapaiannya cukup berjalan dengan baik. Untuk pelaksanaan kegiatan surveiilans masih belum baik.

Hambatan dari desa siaga adalah pendanaan, tingkat pemahaman dan tingkat pendidikan, aktivitas warga, serta keseriusan stakeholder membina desa siaga. Hambatan untuk program kesiapsiagaan masyarakat adalah masih adanya mitos-mitos tentang merapi, kurangnya pengetahuan masyarakat, kepengurusan yang minim SDM dan terbentur masalah ekonomi. Hambatan pelaksanaan surveilans berbasis masyarakat adalah kurangnya sosialisasi, kurang pengetahuan masyarakat, keseriusan puskesmas dan dinas.

Masyarakat menyambut baik dengan adanya Desa Siaga karena dapat menyelesaikan masalah kesehatannya sendiri, menanggulangi bencana, dan meningkatkan kualitas kesehatannya.

\section{DAFTAR PUSTAKA}

Bungin, B. 2007. Penelitian Kualitatif. Prenada Media Group: Jakarta.

Departemen Kesehatan RI., 2006. Pedoman Pengembangan Desa Siaga. Jakarta : Departemen Kesehatan.

Departemen Kesehatan RI, 2010. Pedoman Umum Pengembangan Desa dan Kelurahan Siaga Aktif. Jakarta: Departemen Kesehatan.

Dinas Kesehatan Klaten, 2010. Profil Dinas Kesehatan Klaten. http://www.dinkes klaten.go.id/Diakses pada tanggal 2 April 2011

Departemen Kesehatan RI., 2005. Pedoman Puskesmas dalam Penanggulangan Bencana. Jakarta: Departemen Kesehatan. 
Direktorat Kesehatan dan Gizi Masyarakat. 2006. Kajian Kebijakan Penanggulangan (Wabah) Penyakit Menular (Studi Kasus DBD). Deputi Bidang SDM dan Kebudayaan. Badan Perencanaan Pembangunan Nasional.

Departemen Kesehatan RI. 2007. Keputusan Menteri Kesehatan Republik Indonesia Nomor 747/Menkes/SK/VI/2007.

Hermansyah. A. 2008. Persepsi Stakeholder terhadap Pelaksanaan Desa Siaga di Kabupaten Sambas tahun 2007. Tesis. Universitas Gadjah Mada. Yogyakarta

Laporan Hasil Kegiatan Tahun 2007 dan Program Kerja Tahun 2008. Forum Desa Siaga Desa Rasau Kecamatan Pamenang Kabupaten Merangin Provinsi Jambi Tahun Buku 2007.

Patramanda, A. 2010. Analisis Perilaku Hidup Bersih dan Sehat (PHBS) terhadap Pelaksanaan Desa Siaga di Desa Margomulyo, Yogyakarta: FK UII

Pan American Health Organization., 2006. Bencana Alam : Perlindungan Kesehatan Masyarakat. Jakarta: EGC.

Permanasari, H., 2010. Analisis Kesiapsiagaan Masyarakat dalam Menghadapi Bencana Gunung Merapi Pada Pelaksanaan Desa Siaga di Desa Umbul Harjo Cangkringan Sleman. Yogyakarta: FK UII.

Sugiyono. 2008. Memahami Penelitian Kualitatif. Alfabeta: Bandung.

Syahputra, H., dan Eliza, N. 2010. MDGs dan Pengurangan Risiko Bencana. http:/ / health.kompas.com/read/2010/10/20/01295663/MDGs.dan.Pengu rangan.Risiko.Bencana.Diakses tanggal 8 Juni 2011

Trisnantoro, L., Sanusi, R., Susanto, N., Fatimah, I., Fuad, A. 2007. Pelaksanaan Desentralisasi Kesehatan di Indonesia 2000-2007: Sistem Surveilans yang Dirancang Pemerintah Pusat.

Zuhriyatin, Y. 2009. Peran Perawat Puskesmas pada Tahap KesiapsiagaanBencana di Kabupaten Sleman Yogyakarata. Skripsi : Program Studi Ilmu Keperawatan UGM. 